\title{
Comparative evaluation of the effects of short-term inhalation exposure to diesel engine exhaust on rat lung and brain
}

\author{
Damien van Berlo • Catrin Albrecht • Ad M. Knaapen · Flemming R. Cassee • \\ Miriam E. Gerlofs-Nijland • Ingeborg M. Kooter • Nicola Palomero-Gallagher • \\ Hans-Jürgen Bidmon · Frederik-Jan van Schooten · Jean Krutmann • Roel P. F. Schins
}

Received: 15 March 2010 / Accepted: 22 April 2010 / Published online: 14 May 2010

(c) The Author(s) 2010. This article is published with open access at Springerlink.com

\begin{abstract}
Combustion-derived nanoparticles, such as diesel engine exhaust particles, have been implicated in the adverse health effects of particulate air pollution. Recent studies suggest that inhaled nanoparticles may also reach and/or affect the brain. The aim of our study was to comparatively evaluate the effects of short-term diesel engine exhaust (DEE) inhalation exposure on rat brain and lung. After 4 or $18 \mathrm{~h}$ recovery from a $2 \mathrm{~h}$ nose-only exposure to DEE $\left(1.9 \mathrm{mg} / \mathrm{m}^{3}\right)$, the mRNA expressions of heme oxygenase-1 (HO-1), inducible nitric oxide synthase (iNOS), cyclooxygenase-2 (COX-2), and cytochrome P450 1A1 (CYP1A1) were investigated in lung as well as in pituitary gland, hypothalamus, olfactory bulb, olfactory tubercles, cerebral cortex, and cerebellum. HO-1 protein expression in brain was investigated by immunohistochemistry and ELISA. In the lung, $4 \mathrm{~h}$ post-exposure, CYP1A1 and iNOS mRNA levels were
\end{abstract}

D. van Berlo · C. Albrecht · J. Krutmann · R. P. F. Schins ( $\square)$

Institut für Umweltmedizinische Forschung (IUF)

an der Heinrich-Heine-Universität Düsseldorf gGmbH,

Auf'm Hennekamp 50, 40225 Düsseldorf, Germany

e-mail: roel.schins@uni-duesseldorf.de

A. M. Knaapen · F.-J. van Schooten

Department of Health Risk Analysis and Toxicology,

Maastricht University, Maastricht, The Netherlands

F. R. Cassee · M. E. Gerlofs-Nijland · I. M. Kooter

Centre for Environmental Health,

National Institute for Public Health

and the Environment (RIVM), Bilthoven, The Netherlands

N. Palomero-Gallagher

Institute of Neurosciences and Medicine (INM-2),

Research Center Jülich, Jülich, Germany

H.-J. Bidmon

C \& O Vogt Institute for Brain Research,

Heinrich-Heine-University, Düsseldorf, Germany increased, while $18 \mathrm{~h}$ post-exposure HO-1 was increased. In the pituitary at $4 \mathrm{~h}$ post-exposure, both CYP1A1 and HO-1 were increased; HO-1 was also elevated in the olfactory tuberculum at this time point. At $18 \mathrm{~h}$ post-exposure, increased expression of HO-1 and COX-2 was observed in cerebral cortex and cerebellum, respectively. Induction of HO-1 protein was not observed after DEE exposure. Bronchoalveolar lavage analysis of inflammatory cell influx, TNF- $\alpha$, and IL- 6 indicated that the mRNA expression changes occurred in the absence of lung inflammation. Our study shows that a single, short-term inhalation exposure to DEE triggers region-specific gene expression changes in rat brain to an extent comparable to those observed in the lung.

Keywords Diesel engine exhaust - Nanoparticles $\cdot$ Brain · Oxidative stress $\cdot$ CYP1A1 $\cdot$ Heme oxygenase- 1

$\begin{array}{ll}\text { Abbreviations } \\ \text { BALF } & \text { Bronchoalveolar lavage fluid } \\ \text { BBB } & \text { Blood-brain barrier } \\ \text { COX-2 } & \text { Cyclooxygenase-2 } \\ \text { CYP1A1 } & \text { Cytochrome P450 1A1 } \\ \text { DEE } & \text { Diesel engine exhaust } \\ \text { HO-1 } & \text { Heme oxygenase-1 (HO-1) } \\ \text { IL-6 } & \text { Interleukin-6 } \\ \text { iNOS } & \text { Inducible nitric oxide synthase } \\ \text { PM } & \text { Particulate matter } \\ \text { TNF- } \alpha & \text { Tumor necrosis factor-alpha } \\ \text { VOC } & \text { Volatile organic compound }\end{array}$

Introduction

Diesel engine exhaust (DEE) emissions represent a major source of ambient particulate matter (PM) and 
combustion-derived nanoparticles in most urban settings (Donaldson et al. 2005). Several lines of research have led to the concern that the brain represents a relevant target for the effects of such particles. Initial clues for potential neuropathological effects of ambient air particles have originated from comparative histopathology studies of brains of mongrel dogs, and more recently of postmortem tissues of lifelong residents from cities with strongly contrasting air pollution (Calderon-Garciduenas et al. 2004). These investigations revealed signs of oxidative stress and inflammation in the brain in association with high air pollution, characterized for instance by an increased expression of the transcription factor Nuclear Factor kappa $\mathrm{B}(\mathrm{NF} \kappa \mathrm{B})$ and the inflammatory genes cyclooxygenase-2 (COX-2) and inducible nitric oxide synthase (iNOS) (reviewed in Peters et al. 2006).

Controlled inhalation studies in mice have confirmed that ambient PM and nanoparticles may trigger oxidative stress, toxicity, and inflammation in brain tissue (Campbell et al. 2005; Elder et al. 2006; Kleinman et al. 2008; Veronesi et al. 2005). Moreover, it has been demonstrated that small fractions of inhaled nanoparticles may actually reach the brain (Elder et al. 2006; Oberdorster et al. 2004). For this, two principal routes have been proposed. In the one route, particles are considered to reach brain tissue following deposition on the nasal olfactory epithelium and translocation along the olfactory nerve; the other route involves alveolar deposition and subsequent crossing of the lung blood barrier and the blood-brain barrier (BBB) (Oberdorster et al. 2005; Peters et al. 2006). Under these assumptions, several in vitro studies demonstrated that nanoparticles, including diesel engine exhaust particles, may cause neurotoxic effects to specific brain cells and disturb BBB functions (Block et al. 2004; Hartz et al. 2008; Long et al. 2007).

The objective of the present study was to compare in the rat, the effects of a single, short-term DEE inhalation exposure on both lung and potentially sensitive regions of the brain. The pituitary and hypothalamus were selected because, on the basis of their incomplete BBB, they might be more prone to effects of blood-borne substances. As representative regions for the olfactory translocation route of carbonaceous nanoparticles (Oberdorster et al. 2004), we included olfactory bulb and tubercles. Cerebral cortex and cerebellum were analyzed to obtain a more complete picture of effects in the brain. In each of these brain regions, as well as the lung, the mRNA expression of iNOS, COX-2, heme oxygenase-1 (HO-1) and cytochrome p450 1a1 (CYP1A1) was determined. These genes were selected a priori on the fulfillment of two criteria: (1) their demonstrated relevance in diesel exhaust exposure and lung disease (Ahn et al. 2008; Risom et al. 2003; Takano et al. 2002; Zhao et al. 2006) and (2) their known inducibility in rat brain during oxidative stress, inflammation and/or exposure to polycyclic aromatic hydrocarbons (PAH) (Calderon-Garciduenas et al. 2004; Collino et al. 2006; Colombrita et al. 2003; Maeda et al. 2008; Shimada et al. 2003).

\section{Materials and methods}

Animals

Nine-week-old male Fischer F344 rats, obtained from Charles River (Germany), were used in the present study. Experiments were approved by the Animal Ethics Committee (IUCAC) of the Dutch National Vaccine Institute (NVI). In the week prior to exposure, animals were trained in nose-only tubes for $1 \mathrm{~h}$ daily during 5 days.

\section{Exposure}

The rats were exposed for $2 \mathrm{~h}$, nose-only, to diluted DEE or purified air, followed by an exposure recovery of a further 4 or $18 \mathrm{~h}$ ( $N=8$ per time point). DEE from a stationary (1,500 rpm) diesel engine (35KVA genset, Deutz F3M2011 engine, Bredenoord, Apeldoorn the Netherlands) was mixed with conditioned purified air.

Particle and $\mathrm{NO}_{2}$ levels were closely monitored and regulated to ensure a constant exposure. Particle number and mass concentrations were determined using a condensation particle counter (CPC 3022A, TSI St. Paul, Minn., USA) and a nephelometer (DATARAM 2000, MIE, Billerica, Mass., USA). Time-integrated particle concentrations were determined by gravimetric analysis. A carbon sampler tube was placed downstream of one of the PTFE filters at the outlet to collect the volatile organic compounds (VOC), which were measured by means of GC-MS (RIVM, Bilthoven the Netherlands). The final particle mass concentration in diluted DEE was $1.9 \mathrm{mg} / \mathrm{m}^{3}$ with a geometric mean diameter of $65 \mathrm{~nm}$. Total VOC content was $0.53 \mathrm{mg} / \mathrm{m}^{3}$. The concentrations of $\mathrm{CO}, \mathrm{NO}_{x}, \mathrm{NO}$, and $\mathrm{NO}_{2}$ measured in the mixing chamber were on average $14.23 \mathrm{ppb} \mathrm{CO}$, $2.38 \mathrm{ppb} \mathrm{NO}_{x}, 1.43 \mathrm{ppb} \mathrm{NO}$, and $0.94 \mathrm{ppb} \mathrm{NO}_{2}$.

\section{Necropsy}

Animals were anesthetized 4 or $18 \mathrm{~h}$ post-exposure with a mixture of Ketamin $(100 \mathrm{mg} / \mathrm{ml})$ and Xylazine $(20 \mathrm{mg} / \mathrm{ml})$ in a 10:8 ratio. Animals were then killed through exsanguinations and after saline perfusion of the lungs via the right cardiac ventricle bronchoalveolar lavage was performed. Subsequently, brains were removed. Brains of three DEEexposed and three control animals per time point were immediately incubated in Zamboni's fixative while brains 
Table 1 Primer sequences used in this study

\begin{tabular}{|c|c|c|}
\hline Gene & Forward & Reverse \\
\hline HO-1 & 5'-GGGAAGGCCTGGCTTTTTT-3' & 5'-CACGATAGAGCTGTTTGAACTTGGT-3' \\
\hline iNOS & 5'-AGGAGAGAGATCCGGTTCACAGT-3' & 5'-ACCTTCCGCATTAGCACAGAA-3' \\
\hline $\mathrm{COX}-2$ & 5'-GCACAAATATGATGTTCGCATTCT-3' & 5'-GAACCCAGGTCCTCGCTTCT-3' \\
\hline CYP1A1 & 5'-TGGAGACCTTCCGACATTCATC-3' & 5'-GCCATTCAGACTTGTATCTCTTATGG-3' \\
\hline GAPDH & 5'-TGATTCTACCCACGGCAAGTT-3' & 5'-TGATGGGTTTCCCATTGATGA-3' \\
\hline
\end{tabular}

of five animals per treatment and time point were dissected into six regions, i.e., pituitary gland, olfactory bulb, olfactory tubercles, hypothalamus, cerebral cortex, and cerebellum. Additionally, the accessory lung lobe was removed from the same animals. Brain and lung tissue samples were snap-frozen in liquid nitrogen and stored at $-80^{\circ} \mathrm{C}$ until further processing.

\section{Bronchoalveolar lavage}

The trachea was cannulated and the right lung was lavaged gently in three cycles of inserting and reclaiming the solution with $27 \mathrm{ml}$ saline per kilogram body weight. Bronchoalveolar lavage fluid (BALF) was put on ice immediately and centrifuged at $4{ }^{\circ} \mathrm{C}$ and $400 \mathrm{~g}$ for $10 \mathrm{~min}$. For differential cell counts, the cell pellet was resuspended in $1 \mathrm{ml}$ saline. Cytospin slides were prepared in duplicate for each animal, and after staining with MayGrünwald-Giemsa, 200 cells were differentiated per slide. Total cell numbers in BALF were determined by Coulter Counter. To determine pulmonary toxicity and inflammation, BALF was analyzed for total protein using a reagent kit from Pierce (Etten-Leur, The Netherlands), LDH and alkaline phosphatase using assay kits from Roche Nederland, Almere, The Netherlands. Total Glutathione was measured as described previously (Cassee et al. 2005). Concentrations of the inflammatory cytokines tumor necrosis factor-alpha (TNF- $\alpha$ ) and interleukin-6 (IL-6) in BALF were determined with ELISA kits from Biosource (Etten-Leur, The Netherlands).

\section{Quantitative real-time PCR}

Brain sections and lung tissues were ground and homogenized in Trizol. RNA was extracted according to the manufacturer's instructions and purified using the RNeasy ${ }^{\circledR}$ mini kit in combination with DNAse treatment (RNAse-free DNAse set, Qiagen). From $0.5 \mu \mathrm{g}$ of RNA, cDNA was synthesized using the iScript cDNA Synthesis kit (BioRad, CA, USA) and diluted $15 \times$ in water. qRT-PCR primers were designed for rat HO-1, iNOS, COX-2, CYP1A1, and the housekeeping gene GAPDH, using Primer express software (Applied Biosystems). Sequences are shown in
Table 1. The MyiQ single-color real-time PCR detection system (BioRad) coupled to SYBR ${ }^{\circledR}$ Green Supermix (Biorad), $5 \mu$ diluted cDNA, and $0.3 \mu \mathrm{M}$ primers in a total volume of $25 \mu \mathrm{l}$ was used to perform real-time PCR. Denaturation at $95^{\circ} \mathrm{C}$ for $3 \mathrm{~min}$ was followed by 40 cycles at $95^{\circ} \mathrm{C}(15 \mathrm{~s})$ and $60^{\circ} \mathrm{C}(45 \mathrm{~s})$. Melt curves $\left(60-95^{\circ} \mathrm{C}\right)$ were produced for product identification and purity. PCR efficiencies of all primer sets were in the range of 90-100\%. Gene expression was analyzed using MyiQ Software (BioRad) and normalized to the expression of GAPDH. For the lung, data are expressed as fold-change in expression compared to the expression in air-exposed animals, using the 2- $\Delta \Delta \mathrm{Ct}$ method (Livak and Schmittgen 2001). For the brain, results are shown as expression relative to the mean expression in cerebellum of the air-exposed animals, to allow for comparative evaluation of brain region-specific expression as well as of the effect of DEE.

Brain fixation and immunohistochemistry

For immunohistochemistry, rat brains were immediately incubated in Zamboni's fixative (24 h) and subsequently sucrose $(48 \mathrm{~h})$, and then frozen in isopentane at a temperature of $-40^{\circ} \mathrm{C}$. Brains were stored at $-80^{\circ} \mathrm{C}$ until tissue sections were prepared for the determination of heme oxygenase-1 immunoreactivity as described elsewhere (Bidmon et al. 2001).

\section{Heme oxygenase-1 ELISA}

For all brain sections from the $18 \mathrm{~h}$ recovery time point, except for the pituitary gland due to insufficiency of available material, protein was extracted according to assay kit recommendations (Assay Designs, Ann Arbor, USA). Protein concentrations of all samples were determined using the bicinchoninic protein assay, and all concentrations were adjusted to $2.38 \mu \mathrm{g} / \mu \mathrm{l}$. Samples were then diluted $2 \times$ for the final assay, and $100 \mu \mathrm{l}$ of sample, standard, or buffer control was added per well. The ELISA method was performed according to the manufacturer's guidelines; absorbance was measured immediately at $450 \mathrm{~nm}$. Data are extrapolated from the standard curve and expressed as $\mathrm{pg} / \mathrm{mg}$ total protein. 
Table 2 Bronchoalveolar lavage parameters from rats after 4 or $18 \mathrm{~h}$ recovery from a $2 \mathrm{~h}$ exposure to diesel engine exhaust (DEE) or filtered air

\begin{tabular}{|c|c|c|c|c|}
\hline$B A L F$ & Air, $4 \mathrm{~h}$ & DEE, $4 \mathrm{~h}$ & Air, $18 \mathrm{~h}$ & DEE, $18 \mathrm{~h}$ \\
\hline Total cells $\left(\times 10^{6}\right)$ & $1.17 \pm 0.14$ & $1.34 \pm 0.13$ & $1.14 \pm 0.07$ & $1.05 \pm 0.13$ \\
\hline$\%$ Macrophages & $97.60 \pm 0.17$ & $98.60 \pm 0.32$ & $96.25 \pm 1.15$ & $97.55 \pm 0.45$ \\
\hline$\%$ Neutrophils & $1.30 \pm 0.37$ & $0.90 \pm 0.27$ & $1.80 \pm 0.40$ & $1.50 \pm 0.45$ \\
\hline Total protein $(\mathrm{mg} / \mathrm{l})$ & $215 \pm 12$ & $189 \pm 17$ & $189 \pm 6$ & $205 \pm 14$ \\
\hline LDH (U/l) & $72.6 \pm 6.6$ & $78.9 \pm 5.9$ & $70.2 \pm 1.7$ & $75.7 \pm 7.0$ \\
\hline $\mathrm{AP}(\mathrm{U} / \mathrm{l})$ & $53.9 \pm 4.3$ & $45.5 \pm 1.8$ & $40.3 \pm 6.6$ & $67.3 \pm 5.5^{*}$ \\
\hline Total glutathione $(\mu \mathrm{M})$ & $1.06 \pm 0.07$ & $0.92 \pm 0.10$ & $1.28 \pm 0.12$ & $0.94 \pm 0.09$ \\
\hline $\mathrm{TNF}-\alpha(\mathrm{pg} / \mathrm{ml})$ & $81.9 \pm 22.0$ & $85.7 \pm 19.4$ & $73.6 \pm 18.4$ & $50.8 \pm 9.4$ \\
\hline $\mathrm{IL}-6(\mathrm{pg} / \mathrm{ml})$ & $15.6 \pm 4.1$ & $22.7 \pm 2.7$ & $16.1 \pm 6.6$ & $22.3 \pm 3.2$ \\
\hline
\end{tabular}

Data represent mean \pm SEM from $n=5$ rats per treatment group and time point, $* p<0.05$

\section{Statistical evaluation}

Data are expressed as mean \pm SEM unless stated otherwise. For the evaluation of treatment-related differences (DEE versus air exposure) in lung as well as within specific regions of the brain, data were evaluated by Student $t$ test using SPSS version 15.0 for Windows. A difference was considered to be statistically significant when $p<0.05$.

\section{Results}

Markers of lung toxicity, inflammation, and oxidative stress in BALF

The effects of DEE on BALF markers of cytotoxicity, inflammation, and oxidative stress are shown in Table 2. $\mathrm{LDH}$, total protein, and total glutathione, indicative of toxicity, increased permeability of the alveolar capillary barrier and oxidative stress, respectively, were not significantly increased at 4 or $18 \mathrm{~h}$ post-exposure. Inflammation, measured as increases in total cell number, percentages of neutrophils or macrophages, and levels of TNF- $\alpha$ and IL-6, was also absent at either time point. Alkaline phosphatase, considered as a marker of damage to lung type II epithelial cells, was significantly increased after $18 \mathrm{~h}$ of exposure recovery. Together, these observations demonstrate limited toxicity and the absence of a marked inflammatory response in rat lungs.

Gene expression in rat lungs

The effects of DEE exposure on HO-1, COX-2, iNOS, and CYP1A1 mRNA expression in lung are shown in Fig. 1. The mRNA expression of HO-1 was found to be significantly increased in the lungs from DEE-exposed animals after $18 \mathrm{~h}$ of recovery (1.7-fold increase). For CYP1A1, a statistically significant increase in mRNA was measured
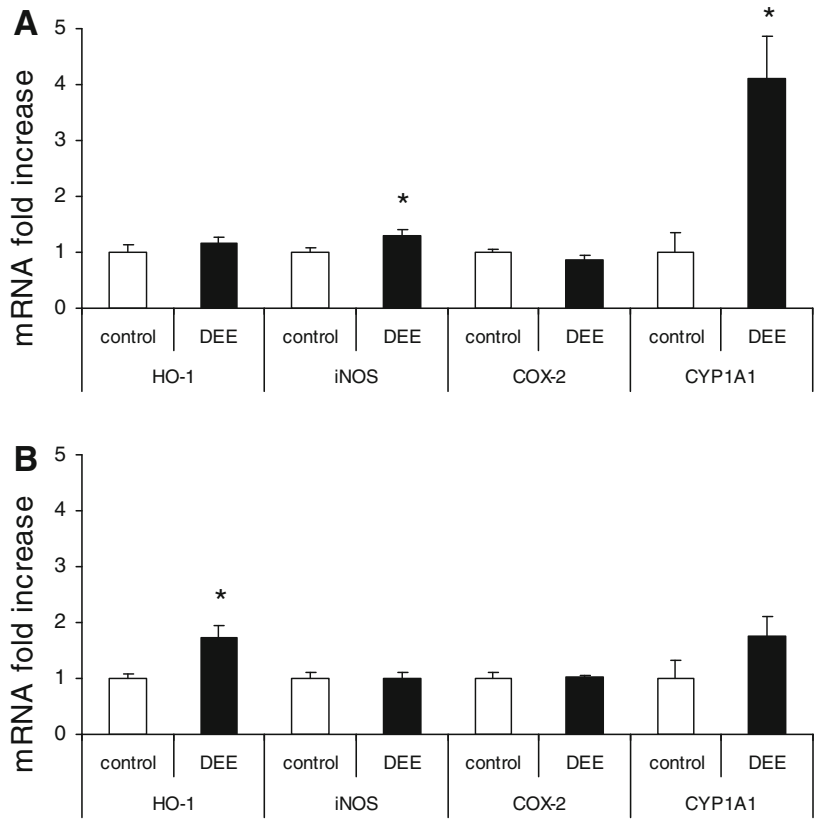

Fig. 1 mRNA expression of HO-1, iNOS, COX-2 and CYP1A1 in rat lungs after $4 \mathrm{~h}(\mathbf{a})$ or $18 \mathrm{~h}$ (b) recovery from diesel engine exhaust (DEE) inhalation exposure. Data represent mean values and standard errors $(n=5)$ and are expressed as GADPH-adjusted fold-increase mRNA expression compared to controls. $* p<0.05$ versus air-exposed group

after $4 \mathrm{~h}$ recovery (4.1-fold). An induction was also observed at $18 \mathrm{~h}$ post-exposure (1.8-fold), but this did not reach statistical significance. A small but significant increase in iNOS mRNA was detected in the lungs of the rats after $4 \mathrm{~h}$ recovery. No changes in COX-2 mRNA expression were observed.

Gene expression in specific regions of the rat brain

The mRNA expression of HO-1, COX-2, iNOS, and CYP1A1 in various sections of the rat brain is shown in Figs. 2 and 3. Data were corrected for GAPDH and 

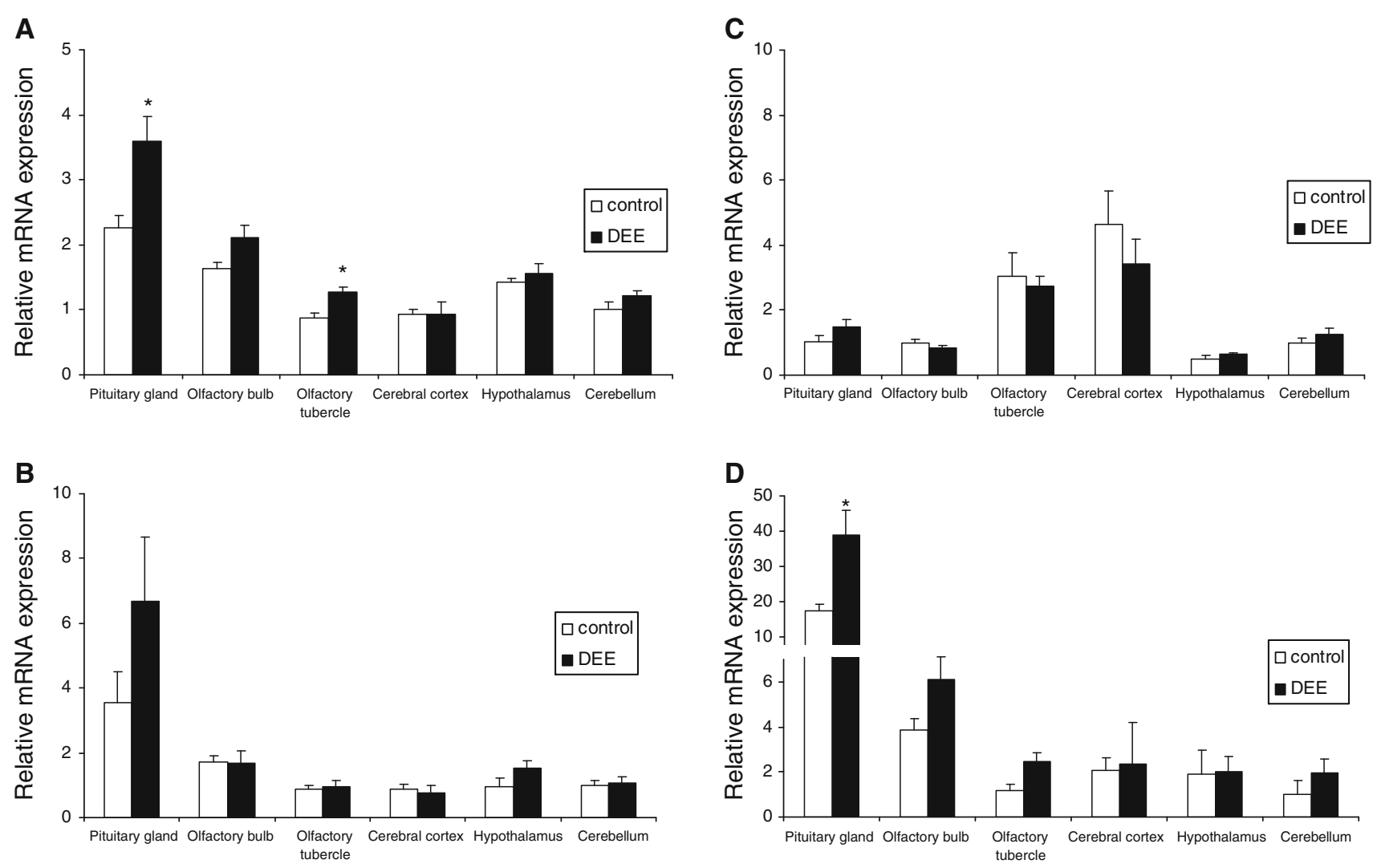

Fig. 2 mRNA expression of HO-1 (a), iNOS (b), COX-2 (c) and CYP1A1 (d) in specific rat brain regions after $4 \mathrm{~h}$ recovery from diesel engine exhaust (DEE) inhalation exposure. Data are shown as mean and SEM ( $n=5$ per treatment) of the GAPDH adjusted mRNA expres-

expressed as fold expression relative to the expression in the cerebellum of the air-exposed rats. For each gene, considerable brain region-specific expression contrasts were found. For HO-1, mRNA expression was found to be highest in pituitary and lowest in both cerebral cortex and cerebellum. In relation to the DEE exposure, HO-1 expression tended to be enhanced in most of the brain regions, both at $4 \mathrm{~h}$ and at $18 \mathrm{~h}$ post-treatment. Statistically significant increases after DEE exposure were found in the pituitary gland and olfactory tubercles after $4 \mathrm{~h}$ and in the cerebral cortex after $18 \mathrm{~h}$. For iNOS, similar to HO-1, the strongest mRNA expression was found in the pituitary glands. In the DEE-exposed animals an approximate twofold increase in the pituitary gland was observed after $4 \mathrm{~h}$. However, this effect did not reach statistical significance because of considerable variation. COX-2 expression was found to be highest in the cerebral cortex and lowest in hypothalamus. At $4 \mathrm{~h}$ post-exposure, COX-2 expression tended to be reduced in cerebral cortex, olfactory bulb and tubercles compared to controls. In contrast, at $18 \mathrm{~h}$ post-exposure, a general tendency of enhanced COX-2 mRNA was observed, reaching statistical significance in the cerebellum only. For CYP1A1 the expression variability in brain was

sion, relative to the mean mRNA expression as measured in the cerebellum of the air-exposed animals for each gene. $* p<0.05$ versus air exposure in the same brain region

found to be most pronounced. Its expression was about 18-20-fold higher in pituitary gland and fourfold higher in olfactory bulb relative to cerebellum. DEE-exposed animals showed a significantly higher CYP1A1 expression in the pituitary gland after $4 \mathrm{~h}$. Notable, but non-significant increases were also observed in cerebellum and olfactory tubercles after 4 and $18 \mathrm{~h}$.

HO-1 protein expression by immunohistochemistry and ELISA

To further evaluate the effects of DEE on rat brain, we also measured HO-1 protein expression by immunohistochemistry and ELISA. Although specific expression profiles were observed for different brain regions, no treatment-related differences were evident upon full evaluation of brain tissue slices. Exemplary, Fig. 4a and b show HO-1 staining in cerebellum of, respectively, a control and a DEE-exposed animal. A clear pattern of HO-1 immunoreactivity was observed irrespective of the exposure, particularly in Purkinje cells. ELISA measurement results are shown in Fig. 4c. Because of insufficiently available material, pituitary gland could not be evaluated. Marked differences were 

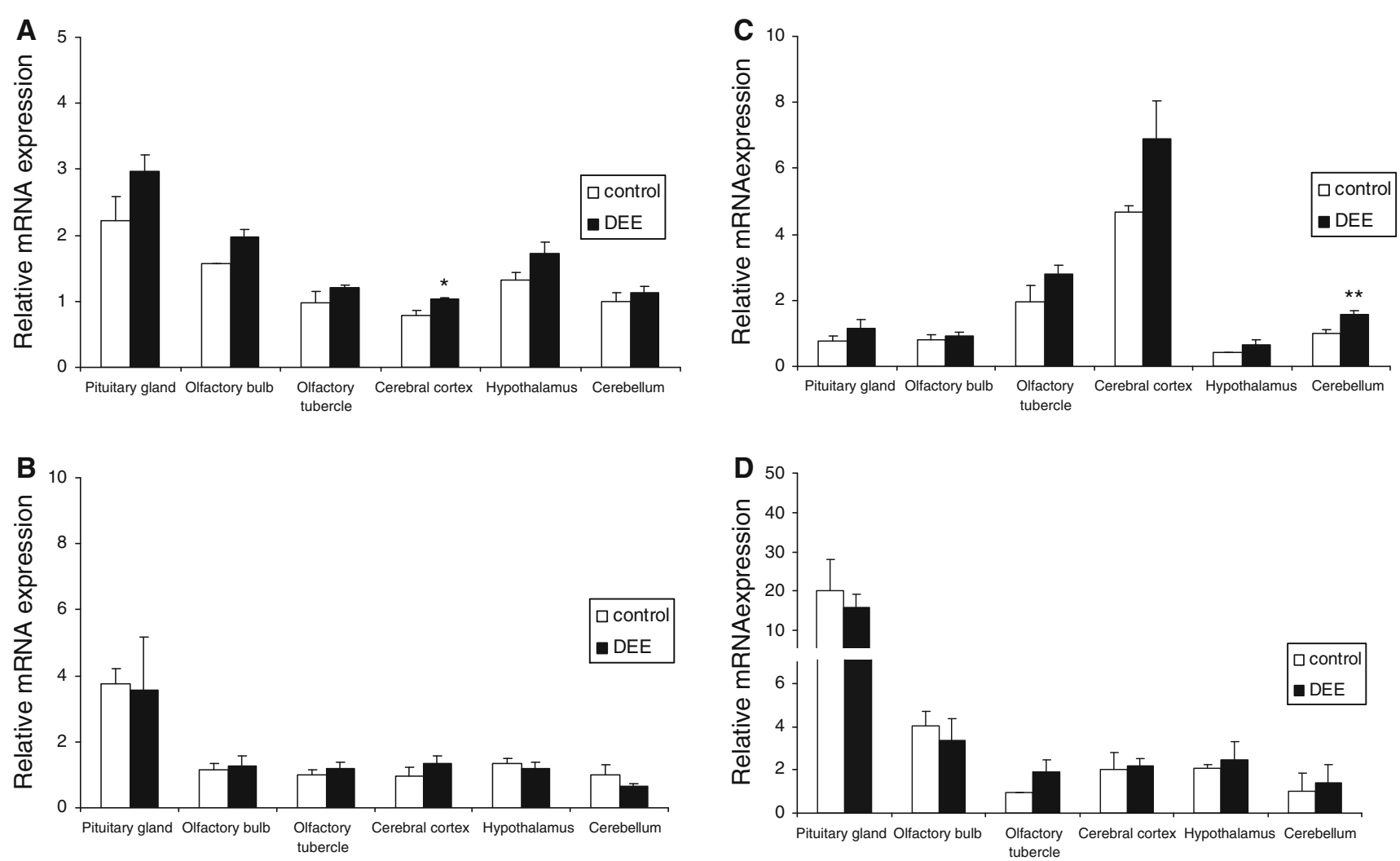

Fig. 3 mRNA expression of HO-1 (a), iNOS (b), COX-2 (c) and CYP1A1 (d) in specific rat brain regions after $18 \mathrm{~h}$ recovery from diesel engine exhaust (DEE) inhalation exposure. Data are mean and SEM
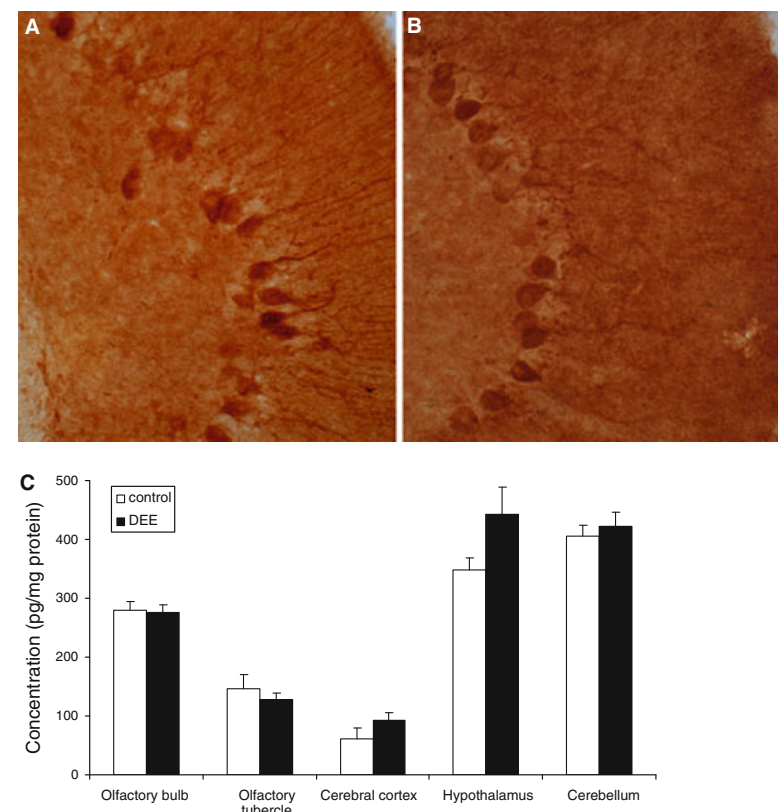

Fig. 4 HO-1 protein expression by immunohistochemistry $(\mathbf{a}, \mathbf{b})$ and ELISA (c) in rat brain tissue after diesel engine exhaust (DEE) inhalation exposure. Representative HO-1 staining in rat cerebellum after $24 \mathrm{~h}$ recovery from a $2 \mathrm{~h}$ exposure to filtered air (a) or DEE (b). Original magnification $\times 25$. Panel $\mathrm{C}$ shows $\mathrm{HO}-1$ expression presented as $\mathrm{pg} / \mathrm{mg}$ total protein, in brain section lysates
( $n=5$ per treatment) of GAPDH adjusted mRNA expression, relative to the mean mRNA expression as measured in the cerebellum. $* p<0.05$ versus air exposure in the same brain region

observed in HO-1 concentrations between the different brain regions, with the highest levels in cerebellum and hypothalamus. In relation to the DEE exposure, no significant differences were found, although tendencies toward upregulation of HO-1 protein were noted in the cerebral cortex and the hypothalamus.

\section{Discussion}

The present study was undertaken to compare the effects of short-term inhalation of diesel engine exhaust on lung and different brain regions of the rat. Among the genes investigated, CYP1A1 tended to show the strongest mRNA expression changes. Our findings suggest a rapid, transient induction upon DEE exposure. The fold increase in CYP1A1 expression in the lung in this study was similar to investigations by Sato et al. (2000), who found a 5.5 -fold induction in rat lungs following 4 weeks of inhalation exposure at $6 \mathrm{mg} / \mathrm{m}^{3}$. Since CYP1A1 induction is considered as a sensitive marker of exposure to diesel engine exhaust particles in the lung (Stoeger et al. 2009; Takano et al. 2002), our current findings suggest that the brain represents a target for DEE. 
Organic constituents adsorbed on diesel particles, PAH in particular, are thought to be crucially responsible for pulmonary CYP1A1 induction (Bonvallot et al. 2001; Zhao et al. 2006). Whether these are also responsible for CYP1A1 induction in the brain remains to be demonstrated. PAH are highly potent inducers of CYP1A1 in the brain (Shimada et al. 2003). However, deposition and translocation calculations (Oberdorster et al. 2004) indicate that the amount of particles, and hence the ultimate concentration of particlebound PAH and other organic constituents, that may have reached this organ within $6 \mathrm{~h}$ after DEE exposure initiation, will be rather low. Effects of PAH will also depend on their bioavailability, which is known to depend on adsorption strength as well as the amount loaded onto the carbonaceous carrier particles (Gerde et al. 2001). Finally, one should consider a role for (semi)volatile compounds in the present study. For instance, VOC within PM have recently been shown to induce CYP1A1 in vitro (Abbas et al. 2009). Neurotoxic effects of specific VOC are well known. To the best of our knowledge, the CYP1A1-inducing potential in the brain has not been investigated for VOC.

DEE exposure was also associated with expression changes of COX-2 and iNOS. Diesel engine exhaust particles have been shown to increase the mRNA expression of both these genes after instillation in rat or mouse lung (Ahn et al. 2008; Lim et al. 1998; Zhao et al. 2006). In the current $2 \mathrm{~h}$ inhalation study, COX-2 mRNA expression in lung was unaffected, whereas iNOS was rapidly increased. In contrast, this short exposure led in the brain to a significantly increased expression of COX-2, but not of iNOS. Enhanced COX-2 mRNA expression has been observed in the frontal cortex and hippocampus of lifelong inhabitants of cities with high levels of air pollution (Calderon-Garciduenas et al. 2004; Peters et al. 2006). Obviously, these autopsy investigations cannot be directly linked to our study, which addressed potential effects after a single, short-term exposure to DEE. In the human brain autopsy investigations many pollutants other than DEE, as well as independent lifestyle factors might have been responsible for, or contributing to the observed COX-2 expression profiles.

The most consistent effects in our study were found for HO-1, also known as Heat shock protein-32. In concordance with our findings, increased HO-1 mRNA expression has been described in mouse lungs after single and repeated DEE inhalations (Li et al. 2007; Risom et al. 2003). In vitro studies have demonstrated that diesel engine exhaust particles as well as their organic extracts can induce HO-1 in various cell lines ( $\mathrm{Li}$ et al. 2000, 2002). The main mechanism of HO-1-mediated cellular protection is rooted in the powerful antioxidant and anti-inflammatory potential of its metabolic products, like carbon monoxide and bilirubin (Stocker et al. 1987). HO-1 is also well known for its capability to protect brain from oxidative injury and recognized as a sensitive marker of cellular stress responses in this organ (Abraham et al. 1996). Astrocytes highly express HO-1 in response to injury and the $\mathrm{HO}$ pathway has been shown to be a critical defense mechanism for neurons against oxidant aggressors (Chen et al. 2000; Le et al. 1999). In the ischemic rat brain, a common model for oxidative brain damage, a strong rapid induction of HO-1 has been shown (Collino et al. 2006). As such, our current observations indicate that the DEE inhalation triggered a rapid, albeit mild oxidative stress in specific rat brain regions.

Expression changes in HO-1 after DEE exposure could not be confirmed on the protein level by immunohistochemistry. Subsequent analysis by ELISA demonstrated strong region-specific contrasts in expression which were in line with the patterns as observed by immunohistochemistry and described in the literature (e.g. Colombrita et al. 2003). In association with DEE exposure, the ELISA measurements indicated a slight upregulation of HO-1 protein in the hypothalamus and the cerebral cortex, although this did not reach statistical significance. Unfortunately, insufficient material was available for protein expression measurement in the pituitary gland, for which the HO-1 mRNA expression changes after DEE exposure appeared to be the most pronounced.

The overall picture derived from the present study is that short-term exposure of rats to DEE causes mRNA expression changes of genes related to oxidative stress and inflammation in specific brain regions. Moreover, DEE exposure was found to increase the expression of the xenobiotic metabolism enzyme CYP1A1 in the brain. The pituitary gland, which is in direct contact with the hypothalamus, appeared to be most sensitive to the DEE exposure, as indicated by an increased expression of all genes investigated. This suggests that the observed effects of DEE involve the BBB exposure route. At this point it should be noted that the pituitary represents a neuroendocrine organ involved in the orchestration of multiple organs and their functions in a circadian manner via regulatory hormones (DiamantiKandarakis et al. 2009; Melmed 2002). Thus, our data indicate an important route by which effects of DEE may be transmitted to various organs.

However, at $4 \mathrm{~h}$ post-exposure, the expression of HO-1 and CYP1A1 also tended to be higher in olfactory bulb and tubercles. This indicates that the DEE effects may, at least in part, also be mediated via the olfactory route. Interestingly, the pituitary gland and olfactory bulb, both representing "windows of the brain to the outside world" (Feron et al. 2001), also tended to show the highest constitutive mRNA expression for all investigated genes, with the exception of COX-2, for which constitutive expression was highest in the cerebral cortex. Likewise, differences in constitutive expression of these genes throughout the brain 
have been reported by others (e.g. Huang et al. 2000; Maeda et al. 2008; Morse et al. 1998; Quan et al. 1998).

It remains to be investigated whether the observed effects result from direct actions of translocated particles or specific components (e.g. PAH, metals, VOC) carried on the surface of these particles (Donaldson et al. 2005), or whether they are caused indirectly by mediators released from respiratory tract and/or the blood (Peters et al. 2006). In an in vitro experimental model of isolated brain capillaries, diesel engine exhaust particles were recently found to disturb BBB functions through oxidative stress and proinflammatory cytokine production (Hartz et al. 2008). Exposure to diesel exhaust particles can induce systemic inflammation and oxidative stress (Inoue et al. 2006; Yokota et al. 2005), and circulating cytokines are known to evoke inflammatory effects in the brain, including COX-2 induction (Rivest 2001). Although we did not measure specific markers of systemic inflammation or toxicity, such effects are unlikely to provide an explanation for the observed mRNA responses in brain tissue. The DEE exposure did not lead to a notable pulmonary inflammation, measured in BALF as total leukocyte amount, percentage of neutrophils, or the content of the pro-inflammatory cytokines TNF- $\alpha$ and IL- 6 . None of these well-recognized markers for inflammation showed any differences between DEE and control groups. A significant increase was found only for alkaline phosphatase at $18 \mathrm{~h}$ post-exposure, indicative of a delayed selective toxicity to type II lung epithelial cells. However, this does not completely explain the rapid ( $4 \mathrm{~h}$ post-exposure) expression changes in the brain tissue.

At present we do not know whether a single, short exposure to DEE can trigger the effects in human brains that currently were observed in rats. Notably, however, a DEE exposure in human volunteers as brief as $1 \mathrm{~h}\left(0.3 \mathrm{mg} / \mathrm{m}^{3}\right.$ particles) has been shown to induce the pulmonary influx of inflammatory cells as well as to elicit the production and systemic release of inflammatory mediators (Salvi et al. 1999, 2000). As for the genes found to be affected in the brain in our current study, COX-2 has been considered to play a role in the progression of neurodegenerative disorders (Heneka and O'Banion 2007; Teismann et al. 2003) and a deregulation of the HO enzyme system has been linked to Alzheimer's disease and Multiple Sclerosis (Calabrese et al. 2006; Schipper et al. 2000). Cytochrome P450 enzymes like CYP1A1 are, apart from their specific involvement in xenobiotic-induced neurotoxicity, nowadays also considered to play a role in normal brain physiology (e.g. neurotransmitter regulation) as well as in the pathogenesis of Alzheimer's and Parkinson's diseases (Dutheil et al. 2008).

Associations between high (particulate) air pollution and Alzheimer-like pathology features in brain autopsies were shown by Calderón-Garcidueñas et al. (2004). Epidemio- logical evidence has revealed that increased PM levels may also be involved in Multiple Sclerosis relapses (Oikonen et al. 2003). Recently, in a cohort of elderly women mild cognitive function impairments were observed in association with traffic-related exposure, suggesting a role for combustion-derived nanoparticles (Ranft et al. 2009).

Obviously, it is too premature to conclude from our present study that inhalation of diesel engine exhaust particles may contribute to neuropathology. The data from our current study should be viewed alongside the fact that the wellknown pulmonary and cardiovascular health impairments associated with exposure to PM are considered to result from chronic exposures characterized by multiple peak episodes. Therefore, it will be highly relevant to determine whether repeated exposures to combustion-derived nanoparticles can trigger a more persistent oxidative stress and inflammation in brain, and whether such effects can actually cause or accelerate neurodegenerative and neurobehavioral effects.

Our study indicates that short-term exposure to DEE may trigger rapid stress responses and CYP1A1 induction in specific brain regions, most notably in the pituitary. We hypothesize that even short-term exposures to DEE may exert effects in peripheral organs via the pituitary-endocrine axis, which could lead to a more widespread (though not necessarily region-specific) pattern of adverse peripheral reactions. Interestingly, mRNA expression changes in the brains of DEE-exposed rats were similar in extent to those observed in their lungs, a well-known target of DEE. While far lower concentrations of potentially harmful DEE components are expected to reach the brain upon inhalation, this organ is known to be highly sensitive to oxidative stress because of its high energy demands, and its relatively low content of antioxidants (Floyd 1999). Hence, this may explain that even small amounts of toxic substances might induce relevant effects in the brain.

Acknowledgments We thank the members of the Dutch National Vaccine Institute and RIVM, especially John Boere, Daan Leseman and Paul Fokkens, for their experimental assistance. This study is supported by grants from the German Federal Ministry of Environment (BMU), and RIVM, Netherlands (S630111). Sponsors did not participate in study design; collection, analysis, and interpretation of data; and writing of the manuscript.

Open Access This article is distributed under the terms of the Creative Commons Attribution Noncommercial License which permits any noncommercial use, distribution, and reproduction in any medium, provided the original author(s) and source are credited.

\section{References}

Abbas I, Saint-Georges F, Billet S, Verdin A, Mulliez P, Shirali P, Garcon G (2009) Air pollution particulate matter (PM2.5)induced gene expression of volatile organic compound and/or 
polycyclic aromatic hydrocarbon-metabolizing enzymes in an in vitro coculture lung model. Toxicol In Vitro 23:37-46

Abraham NG, Drummond GS, Lutton JD, Kappas A (1996) The biological significance and physiological role of heme oxygenase. Cell Physiol Biochem 6:129-168

Ahn EK, Yoon HK, Jee BK, Ko HJ, Lee KH, Kim HJ, Lim Y (2008) COX-2 expression and inflammatory effects by diesel exhaust particles in vitro and in vivo. Toxicol Lett 176:178-187

Bidmon HJ, Emde B, Oermann E, Kubitz R, Witte OW, Zilles K (2001) Heme oxygenase-1 (HSP-32) and heme oxygenase-2 induction in neurons and glial cells of cerebral regions and its relation to iron accumulation after focal cortical photothrombosis. Exp Neurol 168:1-22

Block ML, Wu X, Pei Z, Li G, Wang T, Qin L, Wilson B, Yang J, Hong JS, Veronesi B (2004) Nanometer size diesel exhaust particles are selectively toxic to dopaminergic neurons: the role of microglia, phagocytosis, and NADPH oxidase. Faseb J 18:1618-1620

Bonvallot V, Baeza-Squiban A, Baulig A, Brulant S, Boland S, Muzeau F, Barouki R, Marano F (2001) Organic compounds from diesel exhaust particles elicit a proinflammatory response in human airway epithelial cells and induce cytochrome p450 1A1 expression. Am J Respir Cell Mol Biol 25:515-521

Calabrese V, Sultana R, Scapagnini G, Guagliano E, Sapienza M, Bella R, Kanski J, Pennisi G, Mancuso C, Stella AM, Butterfield DA (2006) Nitrosative stress, cellular stress response, and thiol homeostasis in patients with Alzheimer's disease. Antioxid Redox Signal 8:1975-1986

Calderon-Garciduenas L, Reed W, Maronpot RR, Henriquez-Roldan C, Delgado-Chavez R, Calderon-Garciduenas A, Dragustinovis I, Franco-Lira M, Aragon-Flores M, Solt AC, Altenburg M, TorresJardon R, Swenberg JA (2004) Brain inflammation and Alzheimer's-like pathology in individuals exposed to severe air pollution. Toxicol Pathol 32:650-658

Campbell A, Oldham M, Becaria A, Bondy SC, Meacher D, Sioutas C, Misra C, Mendez LB, Kleinman M (2005) Particulate matter in polluted air may increase biomarkers of inflammation in mouse brain. Neurotoxicology 26:133-140

Cassee FR, Boere AJ, Fokkens PH, Leseman DL, Sioutas C, Kooter IM, Dormans JA (2005) Inhalation of concentrated particulate matter produces pulmonary inflammation and systemic biological effects in compromised rats. J Toxicol Environ Health A 68:773-796

Chen K, Gunter K, Maines MD (2000) Neurons overexpressing heme oxygenase-1 resist oxidative stress-mediated cell death. J Neurochem 75:304-313

Collino M, Aragno M, Mastrocola R, Benetti E, Gallicchio M, Dianzani C, Danni O, Thiemermann C, Fantozzi R (2006) Oxidative stress and inflammatory response evoked by transient cerebral ischemia/reperfusion: effects of the PPAR-alpha agonist WY14643. Free Radic Biol Med 41:579-589

Colombrita C, Calabrese V, Stella AM, Mattei F, Alkon DL, Scapagnini G (2003) Regional rat brain distribution of heme oxygenase-1 and manganese superoxide dismutase mRNA: relevance of redox homeostasis in the aging processes. Exp Biol Med (Maywood) 228:517-524

Diamanti-Kandarakis E, Bourguignon JP, Giudice LC, Hauser R, Prins GS, Soto AM, Zoeller RT, Gore AC (2009) Endocrine-disrupting chemicals: an Endocrine Society scientific statement. Endocr Rev 30:293-342

Donaldson K, Tran L, Jimenez LA, Duffin R, Newby DE, Mills N, MacNee W, Stone V (2005) Combustion-derived nanoparticles: a review of their toxicology following inhalation exposure. Part Fibre Toxicol 2:10

Dutheil F, Beaune P, Loriot MA (2008) Xenobiotic metabolizing enzymes in the central nervous system: contribution of cytochrome P450 enzymes in normal and pathological human brain. Biochimie 90:426-436
Elder A, Gelein R, Silva V, Feikert T, Opanashuk L, Carter J, Potter R, Maynard A, Ito Y, Finkelstein J, Oberdorster G (2006) Translocation of inhaled ultrafine manganese oxide particles to the central nervous system. Environ Health Perspect 114:1172-1178

Feron VJ, Arts JH, Kuper CF, Slootweg PJ, Woutersen RA (2001) Health risks associated with inhaled nasal toxicants. Crit Rev Toxicol 31:313-347

Floyd RA (1999) Antioxidants, oxidative stress, and degenerative neurological disorders. Proc Soc Exp Biol Med 222:236-245

Gerde P, Muggenburg BA, Lundborg M, Dahl AR (2001) The rapid alveolar absorption of diesel soot-adsorbed benzo[a]pyrene: bioavailability, metabolism and dosimetry of an inhaled particleborne carcinogen. Carcinogenesis 22:741-749

Hartz AM, Bauer B, Block ML, Hong JS, Miller DS (2008) Diesel exhaust particles induce oxidative stress, proinflammatory signaling, and P-glycoprotein up-regulation at the blood-brain barrier. Faseb J 22:2723-2733

Heneka MT, O'Banion MK (2007) Inflammatory processes in Alzheimer's disease. J Neuroimmunol 184:69-91

Huang P, Rannug A, Ahlbom E, Hakansson H, Ceccatelli S (2000) Effect of 2, 3, 7, 8-tetrachlorodibenzo-p-dioxin on the expression of cytochrome P450 1A1, the aryl hydrocarbon receptor, and the aryl hydrocarbon receptor nuclear translocator in rat brain and pituitary. Toxicol Appl Pharmacol 169:159-167

Inoue K, Takano H, Sakurai M, Oda T, Tamura H, Yanagisawa R, Shimada A, Yoshikawa T (2006) Pulmonary exposure to diesel exhaust particles enhances coagulatory disturbance with endothelial damage and systemic inflammation related to lung inflammation. Exp Biol Med (Maywood) 231:1626-1632

Kleinman MT, Araujo JA, Nel A, Sioutas C, Campbell A, Cong PQ, Li $\mathrm{H}$, Bondy SC (2008) Inhaled ultrafine particulate matter affects CNS inflammatory processes and may act via MAP kinase signaling pathways. Toxicol Lett 178:127-130

Le WD, Xie WJ, Appel SH (1999) Protective role of heme oxygenase-1 in oxidative stress-induced neuronal injury. J Neurosci Res $56: 652-658$

Li N, Venkatesan MI, Miguel A, Kaplan R, Gujuluva C, Alam J, $\mathrm{Nel} A$ (2000) Induction of heme oxygenase-1 expression in macrophages by diesel exhaust particle chemicals and quinones via the antioxidant-responsive element. J Immunol 165:3393-3401

Li N, Wang M, Oberley TD, Sempf JM, Nel AE (2002) Comparison of the pro-oxidative and proinflammatory effects of organic diesel exhaust particle chemicals in bronchial epithelial cells and macrophages. J Immunol 169:4531-4541

Li YJ, Kawada T, Matsumoto A, Azuma A, Kudoh S, Takizawa H, Sugawara I (2007) Airway inflammatory responses to oxidative stress induced by low-dose diesel exhaust particle exposure differ between mouse strains. Exp Lung Res 33:227-244

Lim HB, Ichinose T, Miyabara Y, Takano H, Kumagai Y, Shimojyo N, Devalia JL, Sagai M (1998) Involvement of superoxide and nitric oxide on airway inflammation and hyperresponsiveness induced by diesel exhaust particles in mice. Free Radic Biol Med 25:635644

Livak KJ, Schmittgen TD (2001) Analysis of relative gene expression data using real-time quantitative PCR and the 2(-Delta Delta C(T)) method. Methods 25:402-408

Long TC, Tajuba J, Sama P, Saleh N, Swartz C, Parker J, Hester S, Lowry GV, Veronesi B (2007) Nanosize titanium dioxide stimulates reactive oxygen species in brain microglia and damages neurons in vitro. Environ Health Perspect 115:1631-1637

Maeda S, Nakatsuka I, Hayashi Y, Higuchi H, Shimada M, Miyawaki $\mathrm{T}$ (2008) Heme oxygenase-1 induction in the brain during lipopolysaccharide-induced acute inflammation. Neuropsychiatr Dis Treat 4:663-667

Melmed S (2002) The pituitary. Blackwell, Cambridge 
Morse DC, Stein AP, Thomas PE, Lowndes HE (1998) Distribution and induction of cytochrome P450 1A1 and $1 \mathrm{~A} 2$ in rat brain. Toxicol Appl Pharmacol 152:232-239

Oberdorster G, Sharp Z, Atudorei V, Elder A, Gelein R, Kreyling W, Cox C (2004) Translocation of inhaled ultrafine particles to the brain. Inhal Toxicol 16:437-445

Oberdorster G, Oberdorster E, Oberdorster J (2005) Nanotoxicology: an emerging discipline evolving from studies of ultrafine particles. Environ Health Perspect 113:823-839

Oikonen M, Laaksonen M, Laippala P, Oksaranta O, Lilius EM, Lindgren S, Rantio-Lehtimaki A, Anttinen A, Koski K, Eralinna JP (2003) Ambient air quality and occurrence of multiple sclerosis relapse. Neuroepidemiology 22:95-99

Peters A, Veronesi B, Calderon-Garciduenas L, Gehr P, Chen LC, Geiser M, Reed W, Rothen-Rutishauser B, Schurch S, Schulz H (2006) Translocation and potential neurological effects of fine and ultrafine particles a critical update. Part Fibre Toxicol 3:13

Quan N, Whiteside M, Herkenham M (1998) Cyclooxygenase 2 mRNA expression in rat brain after peripheral injection of lipopolysaccharide. Brain Res 802:189-197

Ranft U, Schikowski T, Sugiri D, Krutmann J, Kramer U (2009) Longterm exposure to traffic-related particulate matter impairs cognitive function in the elderly. Environ Res 109:1004-1011

Risom L, Dybdahl M, Bornholdt J, Vogel U, Wallin H, Moller P, Loft S (2003) Oxidative DNA damage and defence gene expression in the mouse lung after short-term exposure to diesel exhaust particles by inhalation. Carcinogenesis 24:1847-1852

Rivest S (2001) How circulating cytokines trigger the neural circuits that control the hypothalamic-pituitary-adrenal axis. Psychoneuroendocrinology 26:761-788

Salvi S, Blomberg A, Rudell B, Kelly F, Sandstrom T, Holgate ST, Frew A (1999) Acute inflammatory responses in the airways and peripheral blood after short-term exposure to diesel exhaust in healthy human volunteers. Am J Respir Crit Care Med 159:702_ 709

Salvi SS, Nordenhall C, Blomberg A, Rudell B, Pourazar J, Kelly FJ, Wilson S, Sandstrom T, Holgate ST, Frew AJ (2000) Acute exposure to diesel exhaust increases IL- 8 and GRO-alpha production in healthy human airways. Am J Respir Crit Care Med 161:550 557
Sato H, Sone H, Sagai M, Suzuki KT, Aoki Y (2000) Increase in mutation frequency in lung of Big Blue rat by exposure to diesel exhaust. Carcinogenesis 21:653-661

Schipper HM, Chertkow H, Mehindate K, Frankel D, Melmed C, Bergman H (2000) Evaluation of heme oxygenase-1 as a systemic biological marker of sporadic AD. Neurology 54:1297-1304

Shimada T, Sugie A, Shindo M, Nakajima T, Azuma E, Hashimoto M, Inoue K (2003) Tissue-specific induction of cytochromes P450 $1 \mathrm{~A} 1$ and $1 \mathrm{~B} 1$ by polycyclic aromatic hydrocarbons and polychlorinated biphenyls in engineered C57BL/6J mice of arylhydrocarbon receptor gene. Toxicol Appl Pharmacol 187:1-10

Stocker R, Yamamoto Y, McDonagh AF, Glazer AN, Ames BN (1987) Bilirubin is an antioxidant of possible physiological importance. Science 235:1043-1046

Stoeger T, Takenaka S, Frankenberger B, Ritter B, Karg E, Maier K, Schulz H, Schmid O (2009) Deducing in vivo toxicity of combustion-derived nanoparticles from a cell-free oxidative potency assay and metabolic activation of organic compounds. Environ Health Perspect 117:54-60

Takano H, Yanagisawa R, Ichinose T, Sadakane K, Inoue K, Yoshida S, Takeda K, Yoshino S, Yoshikawa T, Morita M (2002) Lung expression of cytochrome P450 1A1 as a possible biomarker of exposure to diesel exhaust particles. Arch Toxicol 76:146-151

Teismann P, Vila M, Choi DK, Tieu K, Wu DC, Jackson-Lewis V, Przedborski S (2003) COX-2 and neurodegeneration in Parkinson's disease. Ann N Y Acad Sci 991:272-277

Veronesi B, Makwana O, Pooler M, Chen LC (2005) Effects of subchronic exposures to concentrated ambient particles. VII. Degeneration of dopaminergic neurons in Apo E-/- mice. Inhal Toxicol 17:235-241

Yokota S, Seki T, Furuya M, Ohara N (2005) Acute functional enhancement of circulatory neutrophils after intratracheal instillation with diesel exhaust particles in rats. Inhal Toxicol 17:671679

Zhao H, Barger MW, Ma JK, Castranova V, Ma JY (2006) Cooperation of the inducible nitric oxide synthase and cytochrome P450 $1 \mathrm{~A} 1$ in mediating lung inflammation and mutagenicity induced by diesel exhaust particles. Environ Health Perspect 114:1253-1258 